\title{
Expression of body and hair color in three adult castes of the red honeybee Apis koschevnikovi von Buttel-Reepen, 1906 in Sabah, Borneo
}

\author{
J Woyke \\ Bee Division, Agricultural University - SGGW, 166 Nowoursynowska, 02-787 Warsaw, Poland
}

(Received 10 December 1996; accepted 15 July 1997)

\begin{abstract}
Summary - Apis koschevnikovi bees were collected in Sabah, Borneo. A total of 303 workers from ten colonies were measured in 1995, and 500 workers, 200 drones and ten queens were investigated in 1996. Measurements were made of the width of the dark bands on terga II, III and IV. Drawings of the different body color patterns were made. The workers are light orange with dark brown bands on abdominal terga. Body color patterns were assigned to five groups. The successive groups are gradually darker. Queens and drones have different color patterns and are darker than the workers. The upper part of the head and the scutum are black, and the dark brown bands on terga are similar in all three bee castes. However, the light colored body parts such as clypeus, scutellum, and the light abdominal bands are light orange or orange in workers and light brown or reddish brown in the sexuals: queens and drones. The major gene responsible for body color in $A$ koschevnikovi is proposed to be designated as $K o$. Hairs covering the thoraces of workers, queens and drones are light orange, gold and gray, respectively. The gene responsible for the color of these hairs is proposed to be designated as $K h$.
\end{abstract}

Apis koschevnikovi / honeybee body color / color differences in castes

\section{INTRODUCTION}

Body color is a striking character of any honeybee. The pattern of light (yellow, orange) and dark (black, brown) color varies between species, within species and between the three castes of adults: workers, queens and drones within the same honeybee colony.
Earlier papers concerning the heredity of body color in honeybees were reviewed by Woyke (1977) and Tucker (1986). Heredity of body color in A mellifera, and especially the bi-modal frequency distribution was explained by Woyke $(1977,1978)$. Woyke $(1995,1997)$ also described major body color genes and their expression in the three castes of adults of four Asian honeybee

Tel: (48) 22 471561; fax: (48) 22 471562; e-mail: woyke@alpha.sggw.waw.pl 
species. A koschevnikovi workers were described by Koschevnikov (1900) as $A$ indica komerunana, by Buttel-Reepen (1906) as $A$ koschevnikovi, and by Maa (1953) as $A$ vechti. This bee was rediscovered by Tingek et al (1988) as $A$ vechti, and by Mathew and Mathew (1988) as $A$ cerana sabahana. A koschevnikovi queens and drones remain undescribed. Therefore, the expression of body and hair color in the three bee castes in a population of $A$ koschevnikovi from Tenom, Sabah, was investigated.

\section{MATERIALS AND METHODS}

Live A koschevnikovi workers, queens and drones were examined in the apiary of the Agricultural Research Station, Tenom, Sabah, Malaysia in March 1995 and October 1996. Together 303 worker bees were sampled from ten colonies in 1995 and 500 from ten colonies in 1996. All bees were preserved in $75 \%$ alcohol. Exact measurements were made on workers collected in 1995. The rest served as control for the general color appearance of worker bees. Two hundred drones from nine colonies were investigated. Only ten queens were examined in detail, although 20 more were observed on combs in bee colonies, and in photos.

Measurements of the width of the dark bands on terga II, III and IV were made under a stereomicroscope with the aid of an eye-piece micrometer in arbitrary units equal to $0.0625 \mathrm{~mm}$. Sometimes the dark hairs of the tomentum had to be scratched off to enable exact measurement of the width of the bands. The sum of the width of the dark bands on the three terga was calculated. Color scale code (Pantone, 1995, 1996) was used to define the body and hair color. Representative specimens of each worker group were drawn. Only one specimen of queens and drones was drawn. Bees under the stereo-microscope were drawn with the aid of a Zeiss drawing apparatus. The drawings were scanned into a computer, and were processed with the aid of the CorelDRAW6 program. These drawings as well as some photos of A koschevnikovi workers and queens are available on the Internet; http://alpha.sggw.waw.pl/ woyke/.

\section{RESULTS}

\section{Body color}

In A koschevnikovi, dense hairs mask the body color of live bees. Variation in body color of worker bees was found. Five different body color types presented in fig 1 (and photos on the Internet) were established from the continuous variations. The five types present the most characteristic representative of each group. The names used in this paper present only the popular color name, which was the closest to the proper color. Exact determinations of the colors are presented in tables I and II according to Pantone (1995, 1996) color-code.

Worker heads are black with some orange-colored parts (fig la). The clypeus, genae, labrum and mandibles are orange. However, in the lightest groups some of the area around the clypeus is orange. In the darkest group, half of the clypeus and the genae are dark. The antennal scapes are orange in workers from groups 1 to 3 , orange-brown in group 4 and brown in group 5. The flagella are brown in all workers. Most of the light areas of thorax and abdomen are light orange or rufus and are lighter than the clypeus. The thorax is covered by hairs masking the body color. The pronotum of the light orange prothorax has a darker area on each side (fig $1 \mathrm{~b}$ and $\mathrm{g}$ ). Most of the mesothorax is dark (fig $1 \mathrm{~g}$ ). The scutum is black in all five groups. However, the scutellum is light orange, and the small plate between it and the scutum, the mesotergum, is a little darker. The two small pleural plates below the wings, the upper and lower epimera, are light brown. The episternum is brown with a round dark brown area in its lower part. The propodeum is light orange with a distinct marked oval curved area. The area is of the same color as the propodeum in the three first groups, and brown in groups 4 and 5, being a little darker in the last group (fig lb). 


\section{Apis koschevnikovi}
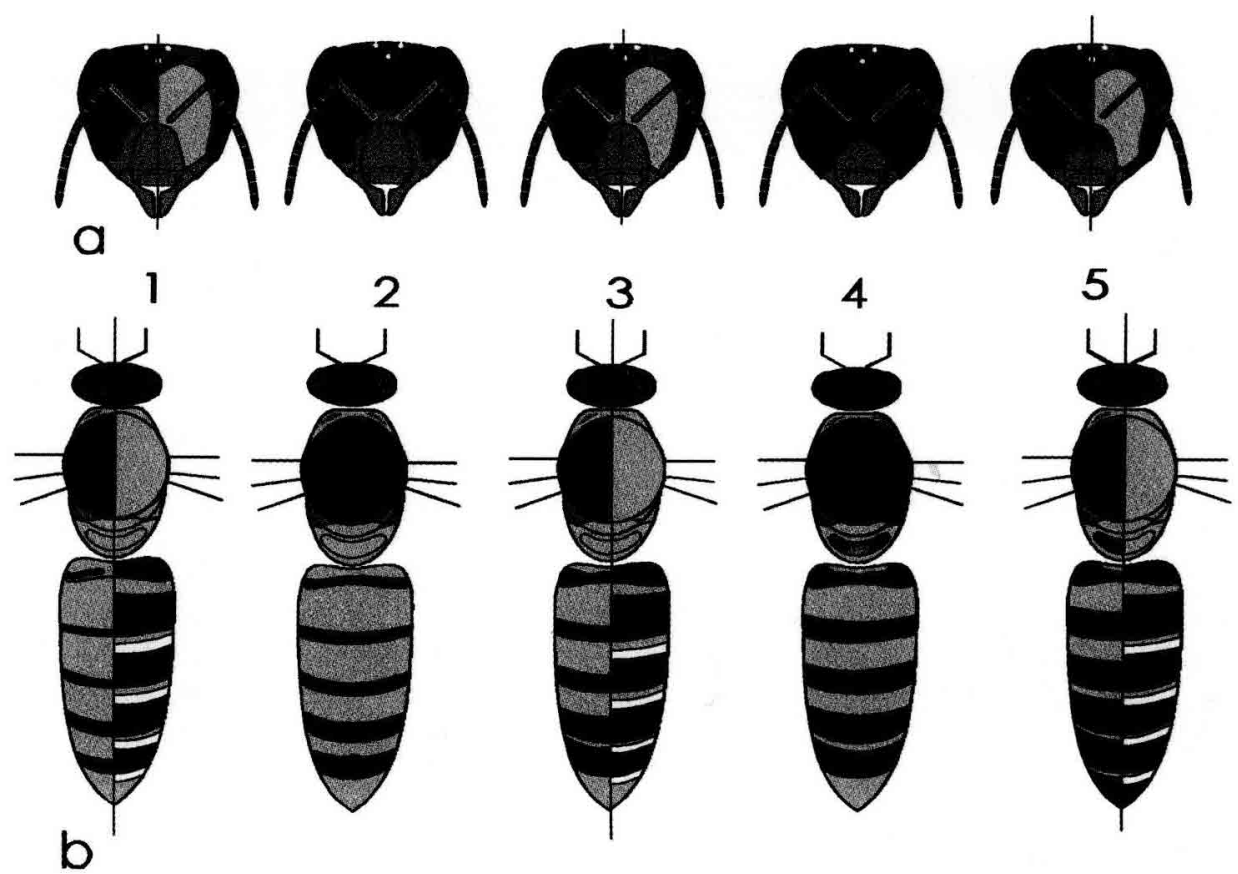

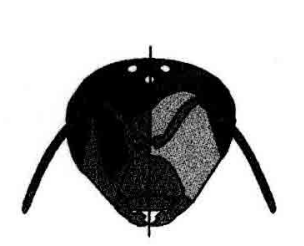

C

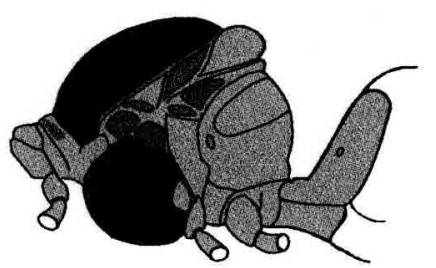

g
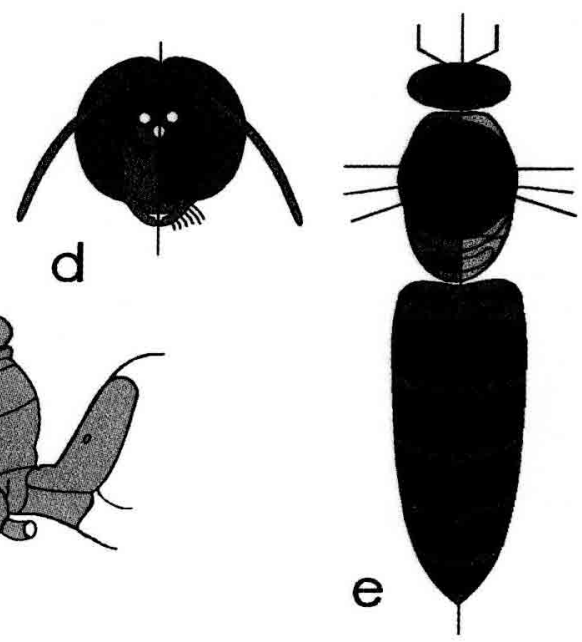

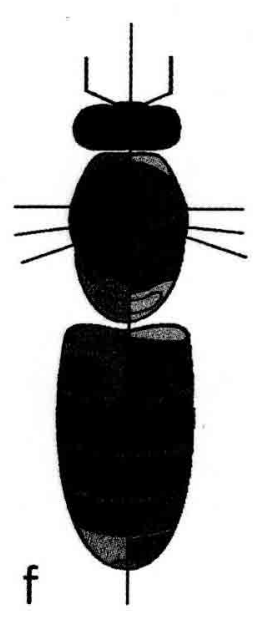

Fig 1. Body and hair color in Apis koschevnikovi. Body parts left of the central vertical line, and those without that line present the color of the body, parts right of that line present the color of hairs covering the body. (a) Heads of workers of five groups; (b) workers of five groups; (c) head of a queen; (d) head of a drone; (e) queen; (f) drone; ( $g$ ) thorax of a worker bee of group 3. 
Table I. Color of different body parts of three adult castes of $A$ koschevnikovi.

\begin{tabular}{|c|c|c|c|}
\hline Body part & Worker & Queen & Drone \\
\hline \multicolumn{4}{|l|}{ Head } \\
\hline Vertex & black & black & black \\
\hline Frons & $\begin{array}{c}\text { black + } \\
\text { orange E 43-2 } \\
20,60,80,0\end{array}$ & $\begin{array}{c}\text { black }+ \\
\text { I brown E 42-2 } \\
30,60,100,30\end{array}$ & $\begin{array}{c}\text { I brown } \\
\text { E 42-2 } \\
30,60,100,30\end{array}$ \\
\hline \multicolumn{4}{|l|}{ Clypeus } \\
\hline Genae & orange E 43-2 & 1 brown E 42-2 & 1 brown E 42-2 \\
\hline Labrum & $20,60,80,0$ & $30,60,100,30$ & $30,60,100,30$ \\
\hline \multicolumn{4}{|l|}{ Mandibles } \\
\hline \multicolumn{4}{|l|}{ Antennae } \\
\hline Scape & $\begin{array}{c}\text { orange E } 43-2 \\
20,60,80,0\end{array}$ & $\begin{array}{c}1 \text { brown E 42-2 } \\
30,60,100,30\end{array}$ & $\begin{array}{c}\mathrm{d} \text { brown E 321-5 } \\
80,90,100,30\end{array}$ \\
\hline Flagellum & $\begin{array}{c}\text { brown E } 317-2 \\
60,80,100,15\end{array}$ & $\begin{array}{c}\text { brown E } 317-2 \\
60,80,100,15\end{array}$ & $\begin{array}{c}1 \text { brown E } 42-2 \\
30,60,100,30\end{array}$ \\
\hline \multicolumn{4}{|l|}{ Thorax } \\
\hline Prothorax & $\begin{array}{c}1 \text { orange E } 37-2 \\
0,50,85,10\end{array}$ & $\begin{array}{c}1 \text { brown E } 42-2 \\
30,60,100,30\end{array}$ & $\begin{array}{c}1 \text { brown E } 39-2 \\
0,50,85,35\end{array}$ \\
\hline Mesothorax & $\begin{array}{c}\mathrm{d} \text { brown E321-1 } \\
80,90,100,30\end{array}$ & $\begin{array}{c}\text { d brown E321-1 } \\
80,90,100,30\end{array}$ & $\begin{array}{c}\text { d brown E321-1 } \\
80,90,100,30\end{array}$ \\
\hline Scutum & black & black & black \\
\hline Scutellum & 1 orange E $37-2$ & 1 brown E $42-2$ & 1 brown E 39-2 \\
\hline Propodeum & $0,50,85,10$ & $30,60,100,30$ & $0,50,85,35$ \\
\hline \multicolumn{4}{|l|}{ Legs } \\
\hline $\begin{array}{l}\text { Coxa } \\
\text { Trochanter } \\
\text { Femur }\end{array}$ & $\begin{array}{c}\text { l orange E } 37-2 \\
0,50,85,10\end{array}$ & $\begin{array}{c}1 \text { brown E 42-2 } \\
30,60,100,30\end{array}$ & $\begin{array}{c}1 \text { brown E 39-2 } \\
0,50,85,35\end{array}$ \\
\hline Tibia & $\begin{array}{c}1 \text { brown } \mathrm{E} 42-2 \\
30,80,100,30\end{array}$ & $\begin{array}{c}1 \text { brown E } 42-2 \\
30,60,100,30 \\
+ \text { dark spots }\end{array}$ & $\begin{array}{c}\text { brown E } 321-1 \\
80,90,100,30\end{array}$ \\
\hline Tarsus & $\begin{array}{c}\mathrm{d} \text { brown E321-1 } \\
80,90,100,30\end{array}$ & $\begin{array}{c}\mathrm{d} \text { brown E321-1 } \\
80,90,100,30\end{array}$ & $\begin{array}{c}\text { d brown E321-1 } \\
80,90,100,30\end{array}$ \\
\hline \multicolumn{4}{|l|}{ Abdomen } \\
\hline Terga & $\begin{array}{c}\text { I orange E37-2 } \\
0,50,85,10+ \\
\text { d brown E321-1 } \\
80,90,100,30\end{array}$ & $\begin{array}{c}\text { red brown E316-5 } \\
40,70,80,0+ \\
\text { d brown E321-1 } \\
80,90,100,30\end{array}$ & $\begin{array}{c}\text { red brown E316-5 } \\
40,70,80,0+ \\
\text { d brown E321-1 } \\
80,90,100,30\end{array}$ \\
\hline Sterna & $\begin{array}{c}\text { gold E } 33-4 \\
0,30,60,5\end{array}$ & $\begin{array}{c}1 \text { brown E 42-2 } \\
30,60,100,30\end{array}$ & $\begin{array}{c}1 \text { brown E 39-2 } \\
0,50,85,35\end{array}$ \\
\hline
\end{tabular}

Abbreviations: d, dark; l, light; red, reddish; + , and. The symbols (E nn-n) indicate the Pantone color identification: E, Euroscale; nn-n, page No and location of color on the page. The four numbers below indicate the percentage of cyan, magenta, yellow and black (CMYK) color in the composed color described. 
Table II. Color of hairs of three adult castes of A koschevnikovi.

\begin{tabular}{|c|c|c|c|}
\hline Body part & Worker & Queen & Drone \\
\hline \multicolumn{4}{|l|}{ Head } \\
\hline Vertex & $\begin{array}{c}\text { gray E } 325-3 \\
0,0,0,70\end{array}$ & $\begin{array}{c}\text { gray E } 325-3 \\
0,0,0,70\end{array}$ & black \\
\hline Frons & $\begin{array}{c}1 \text { orange E } 37-2 \\
0,50,85,10\end{array}$ & $\begin{array}{c}\text { gold E } 33-4 \\
0,30,60,5\end{array}$ & black \\
\hline Clypeus & - & - & black \\
\hline Genae & - & - & - \\
\hline Labrum & - & - & - \\
\hline Mandibles & - & - & - \\
\hline Back of head & $\begin{array}{c}1 \text { orange E } 37-2 \\
0,50,85,10\end{array}$ & $\begin{array}{c}\text { gold E } 33-4 \\
0,30,60,5\end{array}$ & $\begin{array}{c}\text { gold } \mathrm{E} 33-4 \\
0,30,60,5\end{array}$ \\
\hline \multicolumn{4}{|l|}{ Thorax } \\
\hline Prothorax & $\begin{array}{c}1 \text { orange E } 37-2 \\
0,50,85,10\end{array}$ & $\begin{array}{c}\text { gold E } 33-4 \\
0,30,60,5\end{array}$ & $\begin{array}{c}\text { gold E 33-4 } \\
0,30,60,5\end{array}$ \\
\hline Mesothorax & $\begin{array}{c}1 \text { orange E } 37-2 \\
0,50,85,10\end{array}$ & $\begin{array}{c}\text { gold E } 33-4 \\
0,30,60,5\end{array}$ & $\begin{array}{c}\text { gray E } 325-3 \\
0,0,0,70\end{array}$ \\
\hline Scutum & $\begin{array}{c}1 \text { orange E } 37-2 \\
0,50,85,10\end{array}$ & $\begin{array}{c}\text { gold E } 33-4 \\
0,30,60,5\end{array}$ & $\begin{array}{c}\text { gray E } 325-3 \\
0,0,0,70\end{array}$ \\
\hline Scutellum & $\begin{array}{c}1 \text { orange E } 37-2 \\
0,50,85,10\end{array}$ & $\begin{array}{c}\text { gold E 33-4 } \\
0,30,60,5\end{array}$ & $\begin{array}{c}\text { gray E } 325-3 \\
0,0,0,70\end{array}$ \\
\hline Propodeum & $\begin{array}{c}1 \text { orange E } 37-2 \\
0,50,85,10\end{array}$ & $\begin{array}{c}\text { gold E } 33-4 \\
0,30,60,5\end{array}$ & $\begin{array}{l}\text { gold } 33-4 \\
0,30,60,5\end{array}$ \\
\hline \multicolumn{4}{|l|}{ Legs } \\
\hline Coxa & l orange E $37-2$ & gold E 33-4 & gold 33-4 \\
\hline Trochanter & $0,50,85,10$ & $0,30,60,5$ & $0,30,60,5$ \\
\hline Femur & $\begin{array}{c}1 \text { orange E } 37-2 \\
0,50,85,10\end{array}$ & $\begin{array}{c}\text { gold E 33-4 } \\
0,30,60,5\end{array}$ & $\begin{array}{c}\text { gray } \mathrm{E} 325-3 \\
0,0,0,70\end{array}$ \\
\hline \multicolumn{4}{|l|}{ Abdomen } \\
\hline Terga & $\begin{array}{c}1 \text { yellow E } 22-4 \\
0,25,60,0+ \\
\text { d brown E } 321-1 \\
80,90,100,30\end{array}$ & - & $\begin{array}{c}\text { I gold E } 33-4 \\
0,30,60,5+ \\
\text { gray E } 325-3 \\
0,0,0,70\end{array}$ \\
\hline Sterna & $\begin{array}{c}1 \text { orange E } 37-2 \\
0,50,85,10\end{array}$ & - & $\begin{array}{c}\text { gold } E 33-4 \\
0,30,60,5\end{array}$ \\
\hline
\end{tabular}

Abbreviations: d, dark; 1, light, +, and I, 1 st abdominal tergum of drones. For other abbreviations see table I.

The legs are differently colored in workers from different groups. The outside surfaces of the coxae, trochanters and femurs are light orange and the inside surfaces are lighter. The femurs of workers from group 5 are light orange-brown. The tibia is light orange in workers from groups 1 and 2 and light brown in all other groups. Tarsi are dark in workers of all the groups.

The abdominal terga are covered with dense hairs. The terga are light orange with dark bands on their posterior margins. In alcohol-preserved specimens, the light bands become yellow. The color of the dark bands, 
according to CMYK coding is about 80,90 , $100,30 \%$. It can be named as black-brown, dark walnut or dark brown; however, it is not rufus (Rinderer et al, 1989). No distinct difference was noticed in the intensity of that color in workers of particular groups. However, the pattern (width) differed. The band on tergum $I$ in group 1 is interrupted. Figure $1 \mathrm{~b}$ and table III show that the dark bands are wider in successive terga towards the end of the abdomen (mean tergum II-IV; $0.48-0.79 \mathrm{~mm}$, respectively). However, the last tergum VI is light orange, except in group 5 where it is of the same dark brown color as the dark bands on the other terga. Older workers, collected at the hive entrance, lost the dark hairs of the tomentum to different degrees. Thus the light areas of the terga were uncovered, and such bees looked very light in color. The sterna are light orange-gold, being a little lighter than the light tergal bands.

The sum of the width of the dark bands on terga II, III and IV ranged from 0.688 to $3.688 \mathrm{~mm}$ (table III). The mean was $1.88 \pm$ $0.65 \mathrm{~mm}(\bar{x} \pm \mathrm{SD}, n=303)$, the variance 0.43 and the median $1.81 \mathrm{~mm}$. The total range was divided into five groups $0.6 \mathrm{~mm}$ wide (fig 2). The width of the band of the same tergum was wider in successive groups (table III). The mean sums of the three terga ranged in the five groups from 1.06 to 3.33 $\mathrm{mm}$. Thus the dark bands in the darkest group were three times wider than in the lightest group.

Workers of group 2 were the most numerous (about $40 \%$ of the population, fig 2 ). Workers of that group were the most common A koschevnikovi at Tenom. The mode value for that population divided into five groups was $1.59 \mathrm{~mm}$. The frequency distribution is slightly skewed (fig 2) as well

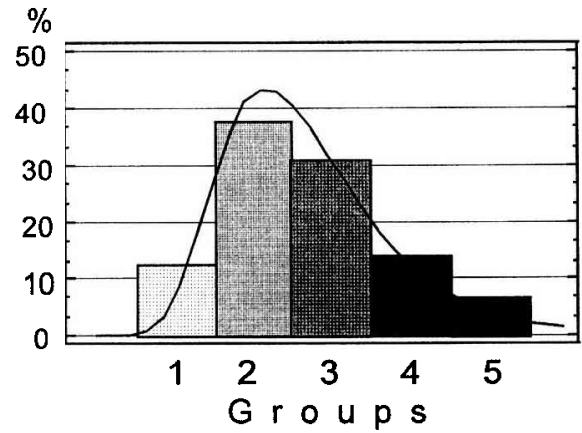

Fig 2. Frequency percentage distribution of five body color groups in A koschevnikovi worker bees. The curve represents the lognormal distribution.

Table III. Width of dark brown bands (in $\mathrm{mm}$ ) on three terga in five groups of $A$ koschevnikovi workers.

\begin{tabular}{|c|c|c|c|c|c|c|c|c|c|}
\hline \multirow{4}{*}{$\begin{array}{l}\text { Group No } \\
\text { All }\end{array}$} & \multirow{4}{*}{$\begin{array}{c}\text { No workers } \\
303\end{array}$} & \multirow{2}{*}{\multicolumn{2}{|c|}{$\begin{array}{c}\text { Tergum II } \\
\text { Range }\end{array}$}} & \multicolumn{2}{|c|}{ Tergum III } & \multicolumn{2}{|c|}{ Tergum IV } & \multicolumn{2}{|c|}{ Sum } \\
\hline & & & & & & & & \multirow{2}{*}{\multicolumn{2}{|c|}{$0.688-3.688$}} \\
\hline & & \multicolumn{2}{|c|}{$0.188-1.188$} & \multicolumn{2}{|c|}{$0.188-1.250$} & \multicolumn{2}{|c|}{$0.313-1.250$} & & \\
\hline & & Mean & $S D$ & Mean & $S D$ & Mean & $S D$ & Mean & $S D$ \\
\hline 1 & 58 & 0.24 & 0.042 & 0.31 & 0.057 & 0.51 & 0.098 & 1.06 & 0.151 \\
\hline 2 & 113 & 0.38 & 0.068 & 0.53 & 0.085 & 0.68 & 0.072 & 1.59 & 0.177 \\
\hline 3 & 76 & 0.55 & 0.073 & 0.71 & 0.061 & 0.92 & 0.092 & 2.18 & 0.162 \\
\hline 4 & 43 & 0.77 & 0.104 & 0.92 & 0.085 & 1.11 & 0.060 & 2.80 & 0.190 \\
\hline 5 & 13 & 1.00 & 0.110 & 1.10 & 0.070 & 1.23 & 0.041 & 3.33 & 0.177 \\
\hline Mean & 303 & 0.48 & 0.213 & 0.61 & 0.226 & 0.79 & 0.231 & 1.88 & 0.650 \\
\hline
\end{tabular}


as the values: for the mean $(1.88 \mathrm{~mm})$, and the median $(1.81 \mathrm{~mm})$ are both below the center of the range $(2.19 \mathrm{~mm})$, being shifted into the direction of the lighter group. The skewness was 0.493 . The frequencies of the five groups fit to a lognormal distribution; $1.885 \pm 0.692 \mathrm{~mm}(\bar{x} \pm \mathrm{SD}), \chi^{2}=4.305, P=$ 0.116 , and do not fit a normal distribution; $1.881 \pm 0.651, \chi^{2}=22.138, P=0.00006$.

The distribution of the five body color groups differed among the ten colonies (fig 3 ). The middle groups 2 and 3 were present in all colonies. All five groups were present in four colonies $(40 \%$ of the investigated population). In other colonies, the lightest or the darkest groups were lacking. The mean of the sum of the width of the dark bands on the three terga (II, III and IV) ranged from 1.43 to $2.73 \mathrm{~mm}$ in the ten colonies (fig 3). The dark bands on terga of workers from colony 14 were almost twice as wide as those were on terga of workers from colony 4 . Analysis of variance showed significant differences between the colonies $(F=155.4, P<0.00005)$. The Duncan multiple range test showed four significantly different groups of means (fig $3, \mathrm{a}-\mathrm{d}$ ). The 95\% LSD test showed even six such groups of means. Thus the width of the dark bands on the terga of workers from different colonies differed significantly.

The color pattern of the queen differs from that of the workers (fig le). The colors are also different (table I and photos on the internet). The clypeus and the other light areas on the queen's head are light brown (fig 1c) and not orange as in workers. The scape is light brown and the flagellum brown. The thorax parts, except the scutum, are light brown and not light orange as in the workers. The oval curved area on propodeum is dark brown as in workers of group 5. The legs are light brown and the tarsi dark brown. The general appearance of the abdomen is similar to workers of the darkest group 5. However, the pattern is different. The dark brown bands on the queen's abdomen are much wider than in workers (fig le). Some variation was observed in the width of the dark bands. The abdomen of some live queens appeared entirely dark brown. However, when the queen curved the abdomen, then the light bands were visible. The abdomens of live queens in weak colonies were contracted, and they looked very dark. In contrast, in strong colonies, the queen's abdomen was extended, and the light bands on the terga were clearly visible. The dark band on segment I is divided into two lighter areas. The last abdominal tergum is also dark, contrary to the light apical tergum of the workers. Only the very tip of the queen's apical segment is light. The narrow light, frontal bands on the terga are reddish brown, contrary to the light orange color in the workers. The sterna are light brown.

The variation of body color in drones was divided into three groups: the lightest, the intermediate and the darkest. More detailed investigation would probably enable a more refined grouping. Only the vertex of the drone head is black. All other parts of the heads are light brown (fig 1d). They are covered with dense dark hairs, so that the entire head of drones appears black. The antennal scape is light brown in the lightest group, brown in group 2 and dark brown in group 3. The flagella are light brown in all the groups. Thus, the scape is darker than the flagellum in drones and lighter in queens. The prothorax, the scutellum and propodeum are light brown, slightly lighter than in the queen. The curved oval area on propodeum is the same color as the propodeum in drones of the lightest group. Darker zones are found on each side of that area in drones of both other groups (fig If). The legs are darker in drones than in workers (table I).

The general appearance of the abdomen is dark brown. Reddish brown bands are present on the anterior part of the terga, and broad dark brown bands on the posterior 

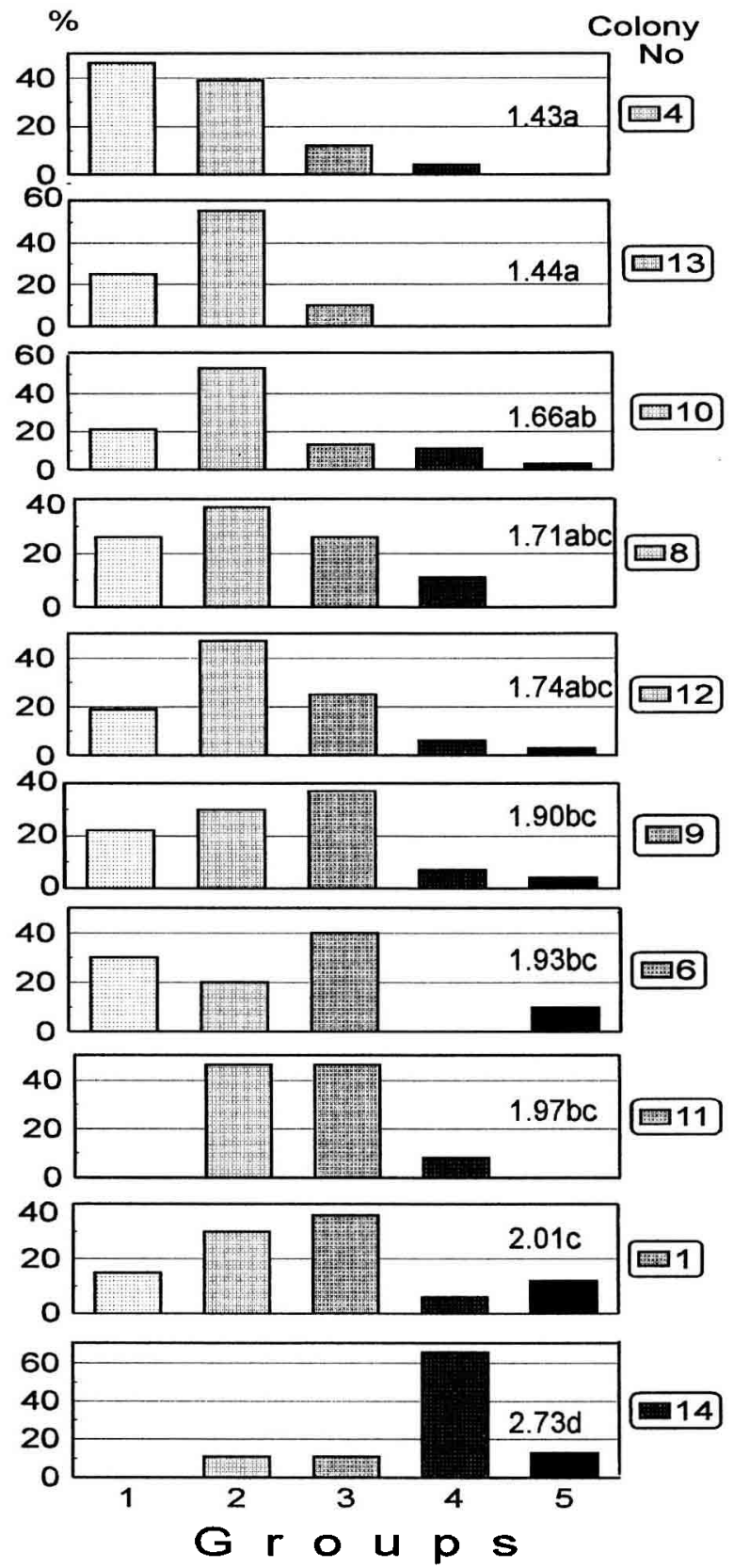

Fig 3. Frequency percentage distribution of five body color groups in ten colonies of $A$ koschevnikovi. Colonies are arranged from the lightest to the darkest. Numbers in graphs present means of the sum of widths of dark bands on three terga of workers from particular colonies. The same letters behind the numbers indicate that no significant differences between the means were found. 
part. The reddish brown color of the frontal tergal area is similar in drones and queens, contrary to the light orange color in workers. Two dark areas are present on each side of tergum II in drones of group 1 (fig 1f). Those areas are larger and connected by a narrow bridge in drones of group 2, and a dark band is present in drones of group 3 . The two last segments are much lighter than the antecedent ones, and their color differs from that of the queen. The two terga are darker in the darkest group. The color of sterna is light brown as in queens and different to that in workers.

The pattern of the dark-colored area is different in all three castes of honeybees. However, the dark brown bands on abdominal terga are of similar color in all three bee castes. The antennal flagella are darker than the scapes in the females (queens and workers) and lighter in drones. The light body color differs in the three bee castes. While some body parts are light orange or orange in workers, they are light brown or reddish brown in queens and drones.

\section{Hair color}

Stereomicroscopic examination revealed that almost all body parts are covered by hairs. However, some parts are sparsely covered. As a result, body color is visible, and those body parts examined with the naked eye or under low magnification $(\times 3)$ look hairless (fig 1). In workers, the clypeus, mouth parts and the genae look hairless (table II). Part of the vertex is covered by gray hairs. The rest of the head, the thorax and three parts of the legs: coxa, trochanter and femur are covered by hairs of the same color, which when examined with the naked eye look light orange. Under the microscope, in natural light, the hairs look gold-yellow. The impression of the color of the hairs depends upon the background and the angle of observation. Hairs protruding backwards from the scutellum look gold-yellow. Hairs covering the propodeum, observed from the top of the bee at a sharp angle, look more reddish.

The terga are covered by broad bands of dark brown (black-brown, dark walnut) hairs. However, the hairs are not orange, as in the photo by Otis in Ruttner (1992), in which the true color is probably altered by photo flash. The color of the hairs is the same as that of the body dark brown bands on abdominal terga. Contrary to the tomentum in $A$ mellifera, the hairs in $A$ koschevnikovi cover the terga up to their rear margin. Light, narrow bands are visible in front of the dark hair bands. Regarding tergum II, this is the body part not covered by hair bands. However, on terga III-VI, narrow bands of light yellow hairs are present (fig 1). The long hairs present on tergum $\mathrm{V}$ of $A$ mellifera are absent in $A$ koschevnikovi. Hairs on tergum VI are scarce; thus the light orange body color of that tergum is visible in workers of groups $1-4$. The sterna are covered with sparse light orange hairs.

The body of the queen is scantily covered by hairs. The vertex of the head is covered by gray hairs. The frons, back of the head, the thorax and the three parts of the legs (table II) are covered with gold hairs. The scutum of the thorax and the abdomen look hairless, although hairs are visible under the microscope.

The head of drones is covered by dense long hairs masking the body color (fig 1). The lower part of the small vertex, the frons, and the clypeus are covered with black hairs. The mouth parts look hairless, except the long black or gray hairs on the outside margin of the mandibles. The back of the head, prothorax, propodeum and the first abdominal segment are covered with gold hairs. However, the mesothorax (scutum and scutellum) and the femurs, especially of the II leg pair are covered with gray hairs. Gray hairs of middle length cover the II abdominal tergum and long ones the terga $\mathrm{V}$ and 
VI. Dorsal parts of terga III and IV look hairless. Thus, the hair colors in drones and females differ very greatly.

\section{DISCUSSION AND CONCLUSIONS}

The above descriptions show, that the expression of the body color is different in the three castes of bees. The light-colored body parts like clypeus, scutellum and the abdominal light bands are orange or light orange in workers and light brown or red-brown in queens and drones. Thus, the body color expression is linked to sexuality. It is orange in the infertile workers and brown in the sexuals: queens and drones. The dark abdominal bands are of the same dark brown color in all three types of bees. Thus a natural cross of brown, dark-banded queen with brown, dark-banded drones results in orange, dark-banded workers. I propose to designate the gene responsible for the expression of the body color in $A$ koschevnikovi as the Ko gene. Considerable variation in the width of the dark abdominal bands was found. Unimodal distribution of the frequencies presented in this paper points to the simplest explanation of the results, as the presence of several polygenes with a cumulative effect. The polygenes are treated as modifiers of the major body color gene $K o$. Interaction of environmental conditions such as temperature in $A$ cerana workers (Tsuruta et al, 1989) or $A$ mellifera queens (Spivak et al, 1992) should also be considered. However, even in constant temperature in an incubator considerable color variation occurred in both species of bees. This indicates that several genes (modifiers) are responsible for the variation. The presence or absence of some color groups of workers in particular bee colonies depends probably upon the color of the queens and the drones that mated them.

The thorax of the females is covered by light orange and gold hairs in workers and queens, respectively. However, the mesotho- rax of drones is covered by gray hairs. I propose to designate the gene responsible for the expression of the color of hairs covering the thorax (strictly mesothorax) as the $K h$ (Koschevnikovi hairs) gene. The expression of that gene is linked to the caste of the adult bee.

Since A koschevnikovi is a separate species, no crosses can be made with $A$ mellifera, or any other of the four Asiatic bee species. Thus, the Ko gene must be treated as a new one, different from the three major body color alleles $Y, y^{b l}, y^{a c}$ of A mellifera and from the body color genes $A n, F l, D o$, $\mathrm{Ce}$, of the Asiatic honeybees.

\section{ACKNOWLEDGMENTS}

I would like very much to thank J Yapp and Loo Kah Soo from the Rural Development Corporation, Kota Kinabalu for help during my stay in Sabah and S Tingek from the Agricultural Research Station, Tenom, for help in collecting the bees.

Résumé - Expression de la couleur du corps et des poils chez les trois castes d'adultes de l'abeille rouge Apis koschevnikovi von Buttel-Reepen, 1906 à Sabah, Bornéo. La couleur du corps est un caractère marquant chez toutes les espèces ou sousespèces de l'abeille mellifère. La couleur des reines et des mâles d'Apis koschevnikovi n'a pas été décrite jusqu'à présent et celle des ouvrières ne l'a pas été en détail. Des abeilles $A$ koschevnikovi ont été prélevées à Ténom, Sabah, Bornéo. Au total 303 ouvrières issues de dix colonies ont été mesurées en 1995. Cinq cents autres ouvrières issues de dix colonies, 200 mâles issus de neuf colonies et dix reines ont été étudiés en 1996. Les mesures ont porté sur la largeur des bandes foncées des tergites II, III et IV. Les différents motifs de couleurs ont été reportés sur des dessins. Les ouvrières sont orange clair avec des bandes 
brun foncé sur les tergites abdominaux. Elles ont été réparties en cinq groupes de motifs de couleurs de plus en plus foncées (fig 1 ; tableau III). Les cinq groupes étaient présents dans $40 \%$ des colonies, les groupes médians $\mathrm{n}^{\circ} 2$ et 3 l'étaient dans toutes les colonies (fig 3). On a trouvé des différences statistiquement significatives entre les groupes de couleurs dans les diverses colonies. Les reines et les mâles ont des motifs de couleurs différents de ceux des ouvrières et de couleur plus foncée. Les trois castes d'adultes ont la partie supérieure de la tête et le scutum noirs et des bandes brun foncé sur les tergites abdominaux (tableau II). Un croisement naturel entre une reine à bandes brun foncé et des mâles à bandes brun foncé donne donc des ouvrières à bandes brun foncé. Il est proposé de désigner par Ko le gène responsable de l'expression de la couleur du corps chez A koschevnikovi. Les poils qui couvrent le thorax des ouvrières, des reines et des mâles sont respectivement orange clair, couleur or et gris. Il est proposé de désigner par $K h$ le gène responsable de la couleur de ces poils.

\section{A koschevnikovi / couleur du corps / poly- morphisme / caste}

Zusammenfassung - Ausprägung der
Körper- und Haarfarbe bei den drei
Adulttypen der roten Honigbiene Apis
koschevnikovi Buttel-Reepen, 1906 in Sabah, Borneo. Die Körperfärbung ist ein auffälliges Merkmal bei den Arten und Unterarten der Honigbienen. Die Körperfärbung von Königinnen und Drohnen von A koschevnikovi wurde bisher noch nicht, die der Arbeiterinnen nicht im Detail beschrieben. Die Bienen der Art A koschevnikovi wurden in Tenom, Sabah auf Borneo gesammelt. 1995 wurden insgesamt 303 Arbeiterinnen aus zehn Bienenvölkern vermessen. 1996 wurden zusätzlich 500 Arbeiterinnen aus zehn Völkern 200 Drohnen aus neun Völkern und zehn Königinnen unter- sucht. Die Breite der dunklen Bänder auf den Tergiten II, III und IV wurden vermessen. Von den verschiedenen Körperfärbungsmustern wurden Zeichnungen angefertigt. Die Arbeiterinnen sind hellorange gefärbt mit dunkelbraunen Bändern auf den Abdominaltergiten. Sie wurden in fünf schrittweise dunklere Körperfärbungsgruppen unterteilt (Fig 1, Tabelle III). In 40\% der Völker waren Arbeiterinnen aller dieser Gruppen vertreten, die mittleren Färbungsgruppen $\mathrm{Nr} 2$ und 3 gab es in allen Völkern. Zwischen den Bienenvölkern gab es statistisch signifikante Unterschiede in der Zusammensetzung der Färbungsgruppen. Königinnen und Drohnen besitzen unterschiedliche Färbungsmuster und sind dunkler als die Arbeiterinnen. Bei allen drei Honigbienentypen sind Kopf und Scutum dunkel, das Scutellum ist hell, die Tergite haben helle Bänder und die Sternite sind hell gefärbt (Tabelle II). Die natürliche Kreuzung der dunkelbraun gebänderten Königin mit den dunkelbraun gebänderten Drohnen resultiert daher in ebenfalls dunkelbraun gebänderten Arbeiterinnen. Ich schlage vor, das für die Ausprägung der Körperfärbung bei $A$. koschevnikovi verantwortliche Gen als $K o$ zu bezeichnen. Die Thoraxbehaarung der Arbeiterinnen, Königinnen und Drohnen sind hellorange, gold bzw grau gefärbt. Es wird vorgeschlagen, das für die Farbausprägung dieser Haare verantwortliche Gen mit $K h$ zu bezeichnen.

\section{Apis koschevnikovi / Körperfärbung / Honigbienen / Färbungsunterschiede der Kasten}

\section{REFERENCES}

Buttel-Reepen H (1906) Apistica. Beiträge zur Systematic, Biologie, sowie zur geschichtlichen and geographischen Verbreitung der Honigbiene (Apis mellifica $L$.), ihrer Varietäten und der übrigen ApisArten. Mitt Zool Mus Berlin 3, 117-201

Koschevnikov G (1900) [Materials on natural history of honeybees (Apis mellifera L) (Russian)]. Izviestia Imperatorskovo Obshchestva Ljubitelej 
Jestestvoznania, Antropologï i Etnografji. T. 99. Trudy Zoologicheskovo Otdelenija 14, 1-144 + 3 pls

Maa TC (1953) An inquiry into the systematics of the tribus Apidini or honeybees (Hym). Treubia 21, 525-639

Mathew S, Mathew K (1988) The 'red' bees of Sabah. Newsl Beekeepers Tropical Subtropical Countries 12,10

Pantone (1995, 1996) Pantone process color system guide, Euroscale edition. Pantone Inc, Carlstadt, New Jersey, USA

Rinderer TE, Koeniger N, Tingek S, Mardan M, Koeniger $\mathrm{G}$ (1989) A morphological comparison of the cavity dwelling honeybees of Borneo $A$. koschevnikovi (Buttel-Reepen, 1906) and $A$ cerana (Fabricius, 1793). Apidologie 20, 405-411

Ruttner F (1992) Naturgeschichte der Honigbienen. Ehrenwirth, München, Germany

Spivak M, Zoltzer A, DeGrandi-Hofman G (1992) Influence of temperature on rate of development and color patterns of queen honey bees (Hymenoptera: Apidae). Environ Entomol 21, 364370

Tingek S, Mardan M, Rinderer TE, Koeniger N, Koeniger G (1988) Rediscovery of Apis vechti
(Maa,1953): the Sabah honey bee. Apidologie 19, 97-102

Tsuruta T, Matsuka M, Sasaki M (1989) Temperature as a causative factor in the seasonal colour dimorphism of Apis cerana japonica workers. Apidologie 20. 149-155

Tucker KW (1986) Visible mutants. In: Bee Genetics and Breeding (Rinderer TE, ed), Academic Press, Orlando, USA, 57-90

Woyke $\mathbf{J}$ (1977) The heredity of color patterns in the honey bee. In: Genetics, Selection and Reproduction of the Honey Bee. Symposium on Bee Biology, Moscow, USSR, Apimondia Publ House, Bucharest, Romania, 49-55

Woyke J (1978) The heredity of color patterns in the honey bee. In: Biology of Reproduction and Genetics of the Honeybee. Final Technical Report for USDA, Agricultural University of Warsaw, 208231

Woyke $\mathrm{J}$ (1995) Expression of body color patterns in three castes of four Asian honey bees. In: International Conference on Tropical Bees and The Environment, Pedu Lake, Malaysia, 31-32

Woyke J (1997) Body color expression in several species of honey bees. In: Proc 35th Int Apic Congr Apimondia (in press) 